\title{
The Study towards the Traditional Fisherman Survival Mechanism in Facing Famine Season in Meskom Village of Bengkalis Regency, Indonesia
}

\author{
Yoserizal ${ }^{1}$ \\ Ali Yusri1 \\ Zuliskandar Ramli² \\ ${ }^{1}$ Faculty of Social and Political Sciences, Universitas Riau, Pekanbaru 28293, Riau Province, Indonesia \\ Email : yose5918@yahoo.com \\ 2Institute of the Malay World and Civilization (ATMA), Universiti Kebangsaan Malaysia, \\ 43600 Bangi Selangor, Malaysia
}

Doi:10.5901/mjss.2016.v7n4p

\section{Abstract}

Various policies of center government and regency have been implemented to increase fisheman's wealth, by using modern technology and formed the institution that they need. Whereas, a marginalization phenomenon happens, and over fishing trend occurs in many fishing areas. This research was conducted in order to know about traditional fisherman survival mechanism and try to formulate this strategy and try to implement it in meskom Village of Bengkalis Regency, by observing 25 traditional fishermen and 6 informants from fishermen and the parties that understand about the problem in over fishing. The research result shows that the most effective that can be use to fix standard of living and give a chance to traditional fisherman for them to survive by 1) modernisazation, by trying to modernised the traditional fishermen through special programme, like funding funding, using of modern technology and management training of fishery operation; 2) revitalization, by letting traditional fisherman practise their traditional way of fishing and at the same time give a proper facility to them hoping that they can improve their economy and standard of living.

Keywords: Survival mechanism, strategy of making efficient use, traditional fisherman.

\section{Introduction}

In Indonesia, the poverty is a big problem and it's worsen since the monetary crisis happened around the middle of 1997. According to the survey of BPS (Statistic Center Bureau) with UNDP (United Nation Development Programme) and UNSFIR (United Nations Support Facility for Indonesia Recovery) data states that the poor inhabitant in Indonesia in the end of 1998 was around 49.5 millions or 24.2\% (Suara Pembaruan, July 11th 1999). Meanwhile, the total of poor people according to BKKBN (January until March 1999 was about 12.6 million families) (Media Indonesia, July 9th 2009).

The way of prevention and pulling out the fisherman from poverty is done through various ways, one of them is by the programme to help and guide the poor society in order to increase their standard of living. It will be done by digging and developing the potentials in the society, and use it efficiently.

The next data shows a various efforts that been done towards the total of poor people in Indonesia and in Riau Province to improve their standard of living. according to the record of Statistic Center Bureau (BPS) National, the precentage of poor people total decreases from 2008 until 2010, both in Indonesia and in Riau especially (see Table 1).

Table 1. Percentage of Total of Poor People in 2008, 2009. 2010, in Indonesia and Riau Province (\%)

\begin{tabular}{ccccccc}
\hline & \multicolumn{3}{c}{ Riau } & \multicolumn{3}{c}{ Indonesia } \\
\cline { 2 - 7 } & City & Village & City+ Village & City & Village & City+ Village \\
\hline Yr 2008 & 9.12 & 12.16 & 10.63 & 11.65 & 18.93 & 15.42 \\
Yr 2009 & 8.04 & 10.93 & 9.48 & 10.72 & 17.35 & 14.15 \\
Yr 2010 & 7.17 & 10.15 & 8.65 & 9.87 & 16.56 & 13.33 \\
\hline
\end{tabular}

Source : Data of BPS 
Bengkalis Regency is the regency with the highest APBD in Riau Province also has poor traditional fishermen, especially the one who live around the coastal areas. Various policies of center government and government of Bengkalis Regency have been implemented to increase this fisherman's wealth. While others organisation focusing in modernizing their catch means and building institution that they need, but marginalization towards their life happens, even various policies have pushed the situation of over fishing in many areas where they look for the fish.

In order to eliminate the differences in social-economy especially toward the fishermen's, the study towards life defence mechanism of traditional fishermen community that included the obstacle of structural and cultural that they face are very important.

\section{Concept}

Based on the research, the concept or approach that been used are:

(1) Making efficient use. The use of this concept is based on the Guidance Program with a goal to improve the society with a weak economy group (poor), so that they can increase their wealth. This includes giving and or raising "power" to other poeple who is "Powerless". This efford also in hoping to give them motivation.

According to Hikmat (2006), effectiveness is meant as undestanding in psychology of individual control influence towards the situation of social, politic power, and the rights according to regulations. Meanwhile, McArdle (1989) said that this is a decision making process by the targeted people. the people that managed to come to the objective in made efficient through their autonomy, all this result can be seen through their own effort and knowledge accumulation, skill and other sources in order to reach their goal without depending on the help from outside source.

The concept about the making efficient use that is primary used to understand this research is the concept that is revealed by Payne (1997:266), that:

"The making efficient use means to help client to make decision and act for his life with decreasing the impact of social group or personal group in order to train the power, with developing capacity and confidence to use the power, with transfering the power from environment to the client".

So the making efficient use tries to develop optimal individu or society of that sort, included accessing the power from environment where they live.

Next, Payne (1997: 268) reveals the opinion of Rees (1991) about the basic power:

"Basic objective from the making efficient use in the opinion of Ress, is social justice that gives the bigger security to the society and social politic equivalence, through supporting each other and learning from small scope to wider goal".

So the making efficient use is based on social justice, where individual or society is the subject that are respected and motivated to increase their life quality. The making efficient use means to direct individual or society to use the change as optimum as possible, in order to have better life.

Another concept used to help to understand this research is by Dubois \& Miley, namely the principles and assumptions of making efficient use in social work. Based on the thought of some earlier writers, Dubois and Miley (1992:212) concluded the principles and assumptions of making efficient use in social work as follows:

- The making efficient use is a collaboration process, where the client and the maker cooperate as partner.

- The process of making efficient use looks that the client system is competent and able to give access to the sources and change.

- The client must see itself as the causal agent that can influence the change. .

- The competency is obtained or filtered from life experience, especially the experience in strengthening the power, from environment where someone is pointed about what must be done.

- The problem solving, developed from special situation, with various pressures "complexity from factors of double supporter in many problem situations". (Solomon, 1976: 27).

- The informal social net is significant source from stress mediation support and compentency development and someone's control.

- The society must participate in their own making efficient use, goal, meaning, and result must be defined by itself.

- The conciousness level is the key issue in making efficient use, "the knowledge operates action to chance" (Swift \& Levin, 1987: 81). 
- The making efficient use includes access to the sources and capacity to use the sources efectively.

- The making efficient use process is dynamic, sinergistic, and every problem has double solution.

- The making efficient use is goal achievement through personal paralel structure and socio economy development.

Thus, the making efficient use exactly contains its complexity in building human power. The making efficient use needs attitude and strong commitment from the party that is made efficient, so that the goal that is wanted can be reached.

The making efficient use points to people's ability, especially resistant and weak group so they have power or ability in (a) filling basic needs so they have freedom, it means not only free in suggesting opinion, but free from hunger, free from stupidity, free from illness; (b) reaching productive sources that enable them to be able to increase the income and get goods and services that they need; and (c) participating in process of development and decisions that influence them (Suharto 2005).

According to Sumodiningrat (1997: 165), the making efficient use of society is involved tightly with the effort of solving the existing problem, like unemployement, poverty and imbalance in wealth distribution. The effort to make efficient to the society must be done through three ways, which is: (1) Creating situation or atmosphere that enable society's potency to develop. The making efficient use is an effort to build power by pushing, giving motivation, and raising conciousness on potency individual/organisation potency and to develop it; (2) empowering the society that open the access to various change by taking a realistic and positive step; (3) Making efficient use also means protecting. In the process of making efficient must be prevented the weak to be weaker. So the making efficient needs ways or concrete steps to make it true. Without the correct steps, the effort of making efficient will experience many obstacles.

The concept of society's efficiency includes the meaning of community development and community baseddevelopment. The making efficient of society is related tight with the term of society power and develop the involved society power. A citizen with a healthy physically, mentally, educated, strong and innovative indeed do have a power to. The society's power is an elements that enable a society to survive, and in dynamic meaning to develop their self and keep up with the progress. Meanwhile, improving the state of the society is an effort to increase poor society's quality of life to set them free from the the trap of poverty. In other word, improve the society is to make a better society (Kartasasmita, $1996: 1-2)$. So, tt is human development, in the purpose for making efficient the society to be more use in its surroundings.

According to Soemardjan (1997: 2), the poverty is an economy condition (a family/household) that is relatively under the standard of living, compared to the wealth level of material and immaterial from family//household in a certain community. In this context, the poverty happens because the sources been distribution in society is imbalance, so it causes social imbalance in a community in certain area. So it's maybe that a family/household in a certain area is considered relatively poor, but if included the rich people, the data can show much clear around the subjected area.

Meanwhile, Sumodiningrat (1997: 19) reveals that the relative poverty is someone's income that has been above poverty line, but relative lower than the surrounding's income. The relative poverty is related closely with the development problem that has structural characteristic, namely the development wisdom that has not reached yet all societies so it causes income imbalance.

Various definitions of poverty generally refer to "the society's ability in filling the economy needs". The people are called poor if they are not able to secure their daily economy needs to survive. Whereas the poverty often is only impact from another poverty like poverty of social and politic access. The people that don't have sufficient access towards social and politic institution will be hard to get proper work and income.

According to Kusnadi (2004), the fishermen's poverty is caused by complex factor that related with each other. The factors can be categorized as internal and external factor. The internal factor is the factor that is related to the fishermen themselves like their willingness and man power. The external factor is a factor that related with the weather condition and outside element.

Thus, the poverty is not only economy problem, but also involved other problems. In order to curb the poverty successfully, another factor also need to be considered as its affect the poor economy as well.

\section{Methodology}

This is a descriptive research by using qualitative approach. Meanwhile, the basic theoretical understanding is phenomenological that tries to understand human life from their ownself in the connection with certain situations (Alston \& Bowles 1998). The phenomenonlogical doesn't assume that the research knows meaning of something for observed people. The follower of phenomenonlogical presses subjective aspect from people behaviour. They try to enter into the 
conceptual world of the observed subjects like that so they understand what and how a meaning is developed by them around occasion in their daily life. (Maleong, 1998: 9). Thus, the phenomenonlogy lets informant to give information or illustration and own perception about situation that they experience, without influenced by anyone out of itself. With this approach, the research result is hoped to be able to enlighten the true fact about the subject studied.

\subsection{Informant}

Because of this research is case study and uses qualitative approach, so the informant is chosen based on certain criteria, because it's to get a wide picture about the effectiveness in following various efficiency programs in their village. The informant in this research is a traditional fisherman that is considered to understand the impact of various efficiency programme in their villages directly or indirectly. Later on, 10 informants will be chosen in this research, 4 people are the main informants and others are additional informants. 4 primary informants are taken from traditional fishermen that have become fishermen for more than 20 years, meanwhile additional informants consist of : 1) Fishery and Sea Official; (2) Cooperation and UKM Official; (3) BPMDKS; (4) The Head of Village; (5) The Head of LKMD; (6) The Head of Fisherman Group. Meanwhile, for getting illustration about poverty phenomenon, observed 25 traditional fishermen that were decided purposively, based on work characteristic that is wanted in the research object.

\section{Result and Discussion}

\subsection{Economy Condition}

The economy of Mescon Village community especially the traditional fishermen are basically depended on sea. They fully depended on the tide seasons as this season influence and affected their catch. Other nature factor also need to be taken into consideration like when the fish is hiding underwater and not coming out. If this happen, the traditional fishermen will live in poverty without any catch.

The economic situation for the traditional fishermen is bad as they only can earn enough for themselves and its different compared to the modern fishermen who usually got an average income. From 25 traditional fishermen families interviewed, only $35 \%$ said that they earn enough for themselves, $62 \%$ said that they didn't earn enough while only $3 \%$ said they have more than enough.

It's different with modern fisherman that live on the average income, the economy situation of traditional fisherman is often completely just barely enough, relative poor or very poor (62\%). From 25 traditional fishermen families that are observed only $35 \%$ feel that they have enough for living and $3 \%$ said that they need more. With only 3 month of fishing seasons in a year, it is difficult to survive as their income is little and have less savings.

For the modern fisherman that has boat and production asset, they have more alternative income source other than fishing. Their economy condition won't be relative influenced by season, but these people can be counted in the village area of Meskom. It's been stated in this research data from 25 traditional fishermen families that were interviewed, about a half of them convinces their daily needs just barely enough. In the social structure in Meskom village, these traditional fishermen families are generally classified as poor family or little above poverty line or near poor. It can be imagined what will happen if the traditional fihermen families daily income is not stabilized, while the cost of living is rising constantly.

Up till now, many studies find that fishermen are generally the society group that are classified as the poorest (Mubyarto et al. 1984; Kusnadi, 2002), but the traditional fishermen families can be poorer, they are the first victim that suffer and experience maginalization because of modernisation of fishing and economic pressure. Like the fishermen confessson in this research, that in latest year, their economy condition tends to be worse or least still poor like before. From 25 observed traditional fishermen only 15\% told that their standard of living is getting better compared to the previous year.

For the society citizen in Meskom village like traditional fishermen families, the economic pressure is worsen, while the fish becoming scares especially in the water around Bengkalis islands it has been over exploited. The traditional fishermen that only rely on simple technology said that their catch was scarce. Most of informants that were interviewed told that since the last one or two years, the fishing income alone indeed is not enough, except for the boat employer who has net and machine that are able to bring the crewmen to find fish at the middle of the sea.

It is clearly shown that the traditional fishermen who practiced traditional fishing will face a bigger economic problem if the fish is getting scarce.

Someone that works daily as traditional fisherman their income is certainly more or less compared with the 
fishermen who work in a big boat and the difference is if the fisherman worker who get less income because of the climate but they still can afford to have a comfortable life. But, for the traditional fisherman, their income is just barely enough because the fish catch every day is indeed less or even nothing even during the fishing seasons.

According to the confession of observed traditional fisherman, indeed their daily income still can cater their basic daily need. But if the respondent is asked about their child education needs, almost half of respondents often tell that they unable to provide it and half of them tell sometime they can afford it. The same thing also happens when the respondent is asked about their ability to spare a budget for health concern. Half of them said they often can't afford for any medication or treatment when in need. For the poor traditional fisherman family, with a very minimum income and just barely enough for daily living, it will be hard if they have to expand extra budget for having treatment to the doctor or buying medicine in pharmacy, that it si relatively expensive for them.

The poor family that cannot rely on the income from fishing alone usually choose to have another work as an alternative income source especially during the non fishing seasons. But it's not an easy task as there are some factor that often make it difficult. Firstly, it's related with the fisherman education level that is low on an average. For the citizen of Meskom village, especially the one who have skills and high education, they still have another job opportunity instead of fishing. For someone who has a tertiary education, they have a big chance to migrate to the big city for work. But for traditional fisherman who are not educated and don't have alternative skill, their life were absolutely depends on the result fishing.

Secondly, most of the respondent didn't have any alternative skills or even they have but it's limited. For example, there is a potential in a small industry but most of the respondent said that they don't have a skill needed to participate although the government had given a budget needed and the programme failed.

Thirdly, it's related with a production asset to support them. The fisherman can have budget and dominate certain kinds of skill, but the next question is: do they develop a new effort or prospect in their production? If the production asset is only dominated by a little part of fishermen. The capital above 1 million or motorcycle to support the traditional fisherman family to improve their standard of living will be meaningless. The observation also shown that there is still a lot of them don't own it even a simple machine to help them fishing. Without having enough facilities it's almost impossible for the poor fisherman family who doesn't have skill to have any alternative way to improve their standard of living.

The findings also shows that most of the fishermen didn't have any alternative job. From the 25 families that been observed, onle a few said that they have another job to do but it's not a daily job. The rest of them said that they has permanent side job but its cant be relied.

In this research when asked about what alternative job to have, most of them answered that they don't have it. From 25 observed families, only some people that have alternative or side work but it's not routine. Meanwhile, a part of them has permanent side work but it's unable to cater the family need.

For poor family in community of Meskom village, what they do to survive is to practice a simple life, eating simple food and sometimes they need to fasting especially the parents to ensure their children have enough to eat. Sometimes, they tend to pawn or sell their good. They also relied on their relative or neighbour as they always help each other and for them this is the most important to ease their life difficulty. According to the poor fishermen, the kind and helpful partner is like a social insurance for them to survive.

\subsection{Business narrative and Survival Mechanism}

For the traditional fishermen especially those that are interviewed in this research, often said that the life indeed doesn't give them many choices. Although they realized that fishing alone can't be relied as their main income. But, because they have already worked in the job for many years, so they must do it willingly and accept it as their destiny.

Many fishermen said that they have worked as traditional fisherman for more than 25 years. At least $2 / 3$ fishermen said that they have worked for more than one decade. From 25 respondent, as much $24 \%$ said that they have worked on this job less than 6 years, and they are classified as a new player in this fishery world. This group generally is young people that continue their parent's legacy as traditional fishermen. From their explanation, it's been said that the opinion of young people that become traditional fishermen were different with young people works in agricultural area, which most of them are determined to pit the fate as migrant or labour worker in foreign country, picking up in a net or fishing with a casting net without any tend to break their fate as fisherman. For a part of young fishermen, the job as fishermen has its own meaning that they must continue.

Rationally, a job doesn't promise a better life, even the result is nil because the resource is scarce. So, there is a need for alternative job. But the most interesting is, alhtough the fate of traditional fishermen is often been related under poverty and experiences maginalization by fishery modernization process, but it appears that many sea village 
community still choose to work as fisherman. Even they have to face a rigid structural poverty, weak competition to fight for natural resources in the sea, and their weak bargaining capabilities in front of the broker. Still, there is a lot of people choose to be a fishermen instead changing their occupation in non-fishery sector.

This study also reveals the main reason why they still want to maintain their job as traditional fishermen. $33 \%$ of the respondent said that there is no alternative job for them. And it's different compared to the big city as there is a lot of job opportunity open for everyone compared to the coastal area.

It will be different if the citizen live in a village with enough and variety of resources as its offer a lot of job opportunity other than only one. But it's unfortunate for the coastal area as the only economy value is fishing. The citizen of Meskom village do face this problem because the area they live didn't offer such opportunity like other sector instead of fishing. And its get worsen as the fish are getting scarce because of over fishing.

$48 \%$ of the 25 traditional fishermen respondent said that they still maintain their work because of the skills. It's because they been practicing fishing since an early age as they been introduced it by their parents. Their parents done this because of their bad economic condition and they decided that the children should help also in order to improve productivity.

For the traditional fisherman family, they still live in poverty even though a lot of trick they tried to improve their life. Like other poor families, they try to solve their problem by making their family productive especially their wife and child.

At the same time, there is another study had been done around 2010 found that the fishermen's wives follow their husband to sell their catch. While others do help in processing shrimp, fish paste or salted fish. Also, there is a case where the wives open a small shop selling their goods around their house.

Their children also do help with their parents work as $21 \%$ of 25 respondent said that their children need to help them to improve their economic condition. Some of them do have a different opinion by letting their wife to take care of children and manage household. They said this because for them going to the sea is a heavy work and it's not suitable for women and children. At the same time, the children need education hoping that they will have a better future compared to their parents.

In the community of Meskom village, the involvement of women and children in productive activity is not something new, although not by going to sea. In the landing of boat or in the coastal area, in going to sea season and many fish, the wives work to carry fish from the boat that has just come. In fish market or fish auction place, the fishermen wives become seller of catch result fish or sell catch result by obtaining as much commission from the seller, as much about $10 \%$ from the total that is succeed to be sold.

In the observed village, the boys usually work to help their parents. They follow their father to the sea during school holiday, or help carrying the catch when the boat land. Besides that, there are also some boys who followed their father or other fishermen to the sea especially the one with relation. Some of the catch will be given to them and been sold at the market and the boys will be able to earn some money.

For the traditional fishermen, they realised that the sea can't be relied much anymore since the modern facility and policy is implemented. There is no more space for traditional fishermen to earn a living. The coastal area once before filled with the traditional fishermen net nowadays is empty. $67 \%$ out of the 25 respondent interviewed said that the total fish catch decreased dramatically and only $5 \%$ said that their catch sometimes increase as they do take a risk to take their boat further to the sea.

A fierce competition from the modern fishermen especially at the market also becoming a serious threat to the traditional fishermen. The respondent said that these modern practitioner do catch as much fish as they can and control the market. The traditional fishermen are in trouble if their income constantly decline as they didn't control the market. This study found that $51 \%$ of the respondent said that their sales at the market is getting difficult and only $9 \%$ said its easier for them to sell their catch while $40 \%$ said there is nothing change.

Based on the observation also can be seen that more than half of the fishermen choose to sell all their catch to the market instead consumed it for themselves. Compared to the small farmer family that will keep some for themselves and sell the rest as they practice self support economy. But for the fishermen community, they more toward commercial economy as they believe by getting money, they can use it for another purpose as well. Its good, but there is a risk need to be taken as the broker tend to buy fish from traditional fishermen with a low price and the fishermen don't have any power to bargain and just need to accept it willingly.

During the non-fishing season, the fishermen didn't go to the sea and most of the traditional fishermen family who have alternative job can still barely able to cater their daily expenses need. But it's unfortunate for the one without any and they need to depend on the 3 month of fishing income to survive for the next 9 month non-fishing season. Sometimes, there is still fish during the 9 month period, but the quantity is extremely low and most of the time there is no catch at all. But, during the monsoon season the fishing activity need to be stopped as the tide is big and most of the time 
they don't have any income. Under this circumstance, sometimes they need to pawn their valuable good.

According to the interviewed fishermen, they do survive the non-fishing season by depending on their saving made during the fishing season, buy only essentials food to survive, working as a fishermen in a big modern ship, making debt, pawn goods and helping others to get pay day.

\subsection{Fishery Modernization}

Like modernisation in agriculture or known as "green revolution", the "blue revolution" is about a programme to modernise the fishermen. But unfortunately, this modernisation led to over fishing. $67 \%$ out of 25 respondent said that their catch is decreasing, $11 \%$ said that their catch is still the same and $22 \%$ said that they getting less. The traditional fishermen can't compete with the modern fishermen as they only used small boat and simple net.

$57 \%$ respondent said that the existence of the modern fishermen do effect their catch and economy. But, they need to satisfy with their catch as it's what they can afford because of their limitation. They also said that if they becoming modern fishermen who operate a big boat, they can increase their income and will become one if the opportunity rise.

Even though there is an awareness in improving their standard of living by becoming a modern fishermen, but there is still an obstacle they need to face. They need to improve themselves as they only have low education, limited skills, and no capital to operate bigger boat. But, they need to improve themselves in order for them to survive the current situation.

\subsection{Efficiency Strategy}

In the framework of improving standard of living for the traditional fishermen in order for them to compete in the current situation, there are two ways that can be implemented. Firstly, by changing them to become modern fishermen. Secondly, by providing them with a proper equipment and facilities.

The two choice proposed however will depend on the government's resources and the fishermen themselves. Also, there is a consideration need to be taken like the traditional fishermen current status like it will be waste if we provide the modern technology directly to them compared to provide it to the organisation they under. But the study in Riau shown that the fishermen there fishing personally by only involving their family not under an organisation (see Table 2).

Table 2. The taking out Strategy of Traditional Fishermen's Poverty

\begin{tabular}{|c|c|c|}
\hline Strategy & Purpose & Program \\
\hline $\begin{array}{l}\text { Traditional Fisherman } \\
\text { Modernization }\end{array}$ & $\begin{array}{l}\text { Giving the chance to traditional fishermen to } \\
\text { change the status to be modern fishermen }\end{array}$ & $\begin{array}{l}\text { - Business capital help } \\
\text { - Modern technology help of fish catch instrument } \\
\text { - Management training of fishery effort }\end{array}$ \\
\hline $\begin{array}{l}\text { Traditional fishermen } \\
\text { revitalization }\end{array}$ & $\begin{array}{l}\text { Strengthening economy buffer and } \\
\text { traditional fishermen bargaining position }\end{array}$ & $\begin{array}{l}\text { - diversification of non-fishery effort } \\
\text { - Business capital help and needs in famine season } \\
\text { through local group that has been made } \\
\text { - Efficiency of women and advanced age of traditional } \\
\text { fisherman family }\end{array}$ \\
\hline
\end{tabular}

Secondly, the long term course by strategically building up a long term investment to improve the subject standard of living. In order to do this, the capital financial aid is needed. At the same time, a god facilities and equipment also need to improve their catch

Third, try to improve their income by improving their self-esteem, changing their mind set of traditional fishermen will stay poor by giving them alternative in the non fishing sector. If they stayed in the sector, their catch will getting less and less as the supply is scares because of overfishing and they didn't own any latest technology. In order to help them, the latest technology and facilities need to be provided

Fourth, try to improve their self esteem in bargaining about the price for their good. Instead of their current fish catch been sold, they also can take a portion of it and process it to make variety product like fermented fish or shrimp. By this processing product, the fishermen can increase the selling price.

Fifth, women participation to improve their family standard of living. The women can take part in arranging and processing the catch. And then they can do some marketing to sell the product. In a long run, the production will expand 
and then they can be given a proper facility and it will benefit them economically in a long term.

Sixth, to break the link of exploitation of fish that affected the traditional fishermen. This is based on the regulative policy from the government. But to make it success, the community development need to be done especially to the targeted subject. If the traditional fishermen can develop something to guarantee their social insurance during bad day they can escape from becoming a debt victim and have a better life.

Seventh, a special and clear programme need for the traditional fishermen who live in Meskom Village as these people do have low education. So the special programme needed in order for the subject to understand and implement it for their own benefit. The programme also must be vary and not depended on meritocratic system. The programme must have a goal in technical aspect, business management and lastly to protect the traditional fishermen to be exploited by the superior economic group.

Lastly, to develop a programme that to accumulate the traditional fishermen income through business diversification. This programme focusing in pushing the traditional fishermen to be more productive until they can compete in the fishery sector or non-fishery sector. Its also in order to improve their work ethic toward professionalism, have access for modern technology in fishing and lastly improving their standard of living.

\section{Observations and Suggestions}

Based on the observation that had been done towards traditional fisherman community in the village of Meskom, Bengkalis Regency. It can be suggest that:

1. The community of Meskom village especially traditional fisherman basically is a society group whose life depends on the sea resources. Like farmer society whose life depends on season rythm, they depend on the tide and fishing seasons to fish.

2. In social structure in Meskom village, these traditional fishermen families generally been categorised as a poor family or little above poverty line or near poor, with the unchanging of the economy condition last year and only $18 \%$ said that their condition are better. The competition from modern fishermen is dense as they control the market and it will eventually kill the traditional fishermen.

3. The poor fisherman family in village of Meskom realizes that they can not rely only on fishing to survive and tries to look for alternative income source from the work in non-fishery sector that is not influenced by season. But the fact, a big part of fishermen answer they don't have side job, only some people that have routine alternative or side job, while a part of them have permanent side job but it can't be relied on.

4. There is a factor to for the observed fishermen to enter another sector is because of their low education level, skill limitation (unskilled) and unproductive as they don't have any equipment to increase their productivity.

5. Although the fate of a big part of traditional fishermen is often under poverty and experiences masginalization by fishery modernization process (limited cross line area and limited catch), but it appears that many communities of sea village that survive do work as fisherman. According to the observed fishermen, it is caused by: 1) going to sea is the only skills they had, because it's gone down from the parents, and involved in fishery economy avtivity since the childhood; 2) there is no another alternative job because there is no alternative resources, because there is no agricultural area and plantation that they can work for.

6. Some survival mechanisms that are implemented are: 1) involving human resource in family at fishery production activity, 2) not doing subsistency economy, but marketing catch result to be more used in needs fulfillment, 3) decreasing daily consumption quality, 4) selling or pawning valuable goods in cooperation or pawn shop, 5) relying on less savings, 6) working as fisherman worker in modern big ship, 7)owning to the neighbour or partner (owner at this moment can not be owning place).

7. Fishery Modernization, obstructed by the things as follows: 1) lack of capital for buying speed boat, and unable to carry on the loan because of various things, 2) lack of independence in working and increasing dependence to other people in operating ship or modern boat, 3) the background of low education, limited skill, and lack of capital, cause doubt to do social mobilization, 4) lack of mastering or unintimate with operating modern boat.

8. In deciding efficiency strategy, to fix life level and give chance to the traditional fishermen in order to be able to do vertical mobility, two ways can be considered, namely: 1) modernization, by pushing status moving of traditional fisherman to be modern fisherman, through program among others. operation capital help, modern technology help of fish catch means, management training of fishery operation; 2) revitalization, by letting traditional fisherman in status "traditional", but giving facility in order to make more efficient use and having ability of family economyaaa buffer that is tough aginst crisis pressure. 


\section{Conclusion}

In social structure in Meskom village the traditional fishermen families generally are poor family or little above poverty line or near poor. Only as much $18 \%$ tell the condition gets better in the previous year. The competition faced by them is also great especially from the modern fishermen who catch fish in the open sea and when selling it to the fish broker as they tend to buy the catch from traditional fishermen at low price. This fishermen also realised that they can't depend on fishing alone to survive and tried to look for alternative income source from another sector. But, only a few can manage to do it whether it's a daily side income routine or not and most of them said that they don't have any side job. Even with all those side job, their live haven't change much. Then, some survival mechanism been implemented like: 1) To involve the family like children and wife to increase productivity, 2) selling all their catch by themselves or process the catch to increase the sell price, 3) decrease daily spending, 4) selling or pawn any valuable good, 5) relying on saving, 6) working in modern fishing ship as fishermen, 7) sharing or partnering with the others

\section{References}

Alston, Margaret \& Bowles, Wendy. 1998. Research for Social Workers An Introduction to Methods). NSW, Australia: Allen \& Unwin.

DuBois, Brenda and Karla Krogsrud Miley. 1992. Social Work: An Empowering Profesion. Boston: Allyn and Bacon.

Hikmat, A. 2006. Community Empowerment Strategy. Bandung: Humaniora Utama Press.

Imron, Masyhuri. 2003. Poversity in fisherman Society. Jurnal Masyarakat Dan Budaya 5(1): 63-82.

Izzedin Bakhit (ed.). 2001. Pounding the roots of poverty Jakarta: Yakoma-PGI.

Sumodiningrat, G. 1997. Regional development and society empowerment. Jakarta : PT. Bina Rena Pariwara.

Kartasasmita, G. 1996. Community Empowerment: Concept Development rooted in community Bandung: Bandung Institute of Technology

Kusnadi, 2002. Fisherman: Adaptation strategy and social networks. Bandung: Humaniora Utama Press.

Kusnadi, 2004, Polemic of fisherman poverty. Bantul : Pustaka Jogja Mandiri

Maleong. 1998. Methodology of qualitative research. CV. Remaja. Rosdakarya Bandung

McArdle, J. 1989. Community Development Tools of Trade. Community Quarterly 16: 47-54

Media Indonesia, July 9th 2009

Mubyarto, Loekman Soetrisno \& Michael, Dove. 1984. Fishermen's and poverty, Study of enenomic anthropology at Dua Desa Rantai. Jakarta: Rajawali Press.

Payne, M. 1997. Social work and community care. London: McMillan

Rees, J. 1991. Natural Resources: Allocation, Ekonomics and Policy Routlege. London and New York: Prederick A. Preager Publisher.

Soemardjan, Selo. 1997. Structural poverty and development. In Alfian et.al. (eds.) Structural poverty. Jakarta: Yayasan IImu-ilmu Sosial.

Suara Pembaruan, July 11th 1999

Suharto, E. 2005. Building society empowering people. Study of development strategy of social welfare and social networks. Sosial. Bandung: PT Refika Aditama. 